\title{
Mielipiteitä aikuisopiskelun rahoittamisesta
}

Maassamme tehdyissä kyselyissä ovat taloudelliset syyt harvoin todettu aikuisopiskelua vaikeuttaviksi tai estäviksi tekijöiksi. Tärkeimpiä syitä aikuisopiskelun ulkopuolelle jäämiseen ovat olleet ajan puute, sopivien koulutusmahdollisuuksien puuttuminen, rasittava työ, korkea ikä, heikko terveys jne. Taloudelliset esteet ja vaikeudet tulevat todella merkittäviksi silloin, kun opiskelu vaatii pidempää työstä irtaantumista.

Aikuisten opintososiaalisen aseman parantaminen on jatkuvasti ollut esillä aikuiskoulutuksen kokonaissuunnittelussa. Vuoden 1985 loppupuolella se nousi uudelleen keskustelun aiheeksi, kun opetusministeriön asettama aikuisopiskelun rahoitusta pohtinut työryhmä sai työnsä päätökseen. Tulopoliittista ratkai- sua tehtäessä vuoden 1986 alussa olivat aikuisten opintotukikysymykset ja henkilöstökoulutus esillä tavanomaista laajemmin.

Aikuiskasvatus -lehti pyysi kolmen vaikuttajatahon - SAK, STK, VOTK - edustajilta näkemyksiä aikuisten opintotuen ja sen rahoittamiseen liittyvistä kysymyksistä. Julkaisemme nämä kirjoitukset seuraavilla sivuilla.

Parhaillaan valmistellaan opintotukilainsäädännön uudistusta opetusministeriössä ja opintovapaalainsäädännön uudistusta sosiaalija terveysministeriössä. Mahdollisesti nämä esitykset tulevat eduskunnan käsittelyyn ensi syksynä.

Pentti Yrjölä 


\section{Näkymiä aikuisopiskelun rahoittamisesta}

Viime syksynä jätti muistionsa aikuisopiskelun rahoitusta pohtinut työryhmä. Tässä artikkelissa tarkastelen niitä ajatuksia, joita työnantajapuolelta on esitetty kyseisestä työryhmän muistiosta.

Yleisenä koulutuksen lähtökohtana voidaan pitää sitä, että päävastuu koulutuksesta on julkisella vallalla. Julkinen koulutusjärjestelmä antaa yleiset ja ammatilliset perusvalmiudet. Kaikilta osin tämä koulutus ei ole riittävää elinkeinoelämän tarpeisiin. Elinikäisessä kasvatuksessa elinkeinoelämän omalla koulutuksella on siten merkittävä sijansa.

Päätösvalta ja vastuu liittyvät kiinteästi toisiinsa. Koulutuksessa tämä merkitsee sitä, että

- valtio ja kunnat vastaavat julkisen koulutuksen kustannuksista

- yritykset vastaavat omasta koulutuksestaan

- yksilöllä on vastuu omasta kehityksestään.

Edellä esitetyt keskeiset lähtökohdat eivät ole toteutuneet aikuisopiskelun rahoitustyöryhmän ehdotuksissa.

Työryhmä ehdottaa, että aikuisopiskelijalle, joksi katsottiin ennen koulutuksen alkamista 24 vuotta, mutta ei 55 vuotta täyttänyt henkilö, joka on ennen opintojen alkua ollut vähintään yhden vuoden päätoimisesti katsottavassa ansiotyössä, tehnyt omaa työtään tai hoitanut omaa tai aviopuolisonsa lasta, vanhempia tai ottovanhempia, maksettaisiin aikuisopintorahana kulukorvausta tai ansiokorvausta kokopäivätoimisen opiskelun aikana.

Kun yksilön vastuuta omasta kehityksestään tuetaan opintotuen muodossa, on tärkeää huolehtia siitä, että tuki kohdennetaan niille, jotka toisaalta ovat tuen tarpeessa ja toisaalta otetaan huomioon samanaikaisesti todellinen halu itsensä kehittämiseen. Näin ollen niitä nykyisessä opintotukilainsäädännössä olevia periaatteita, jotka suuntaavat opintotukea, ei ole syystä romuttaa siten kuin aikuisopiskelun rahoitustyöryhmän muistion sivulla 10 olevan 
luettelon esittämisellä on pyritty tekemään.

Ehdotuksia tehdessään aikuisopiskelun rahoitustyöryhmä on jättänyt ottamatta huomioon ehdotustensa vaikutukset opintojen tukijärjestelmään kokonaisuutena. Ehdotukset ovat suhteettomia perusopintovaiheessa olevien opintotukijärjestelmään nähden. Mainittujen erojen aiheuttamat haittavaikutukset ovat ilmeiset.

Opintotuen muotona kuukausiansioon sidottua ansiokorvausta ei voida pitää sen paremmin oikeuden- kuin tarkoituksenmukaisenakaan. Ehdotus johtaisi siihen, että voisi olla neljänlaista opintotukea saavia saman tyyppisessä koulutuksessa:

- ne, jotka ovat opiskelijoina saamassa peruskoulutustaan

— vähintään vuoden työssä olleet aikuisopiskelijat

- ne aikuisopiskelijat, jotka ovat ansainneet yli $12000,-/ \mathrm{kk}$

- työttöminä olleet aikuisopiskelijat.

Opintotukea annettaessa pitää periaatteena olla, että opiskelijat saavat opintotukea yhtäläisin perustein. Sen, onko peruskoulutusvaiheessa, työelämässä tai työttömänä ei pitäisi vaikuttaa sinänsä tuen myöntämiseen vaan sen, mikä on tarve tuen saamiseen. Tähän vaikuttavat esim. asuuko yksin, onko naimisissa, lasten lukumäärä ja asuuko opiskelupaikkakunnalla. Elinkustannuksia varten itse opiskelijalle tulevan tuen pitäisi olla yhtäläinen niin perusopintovaiheessa olevalle, työssäolleelle kuin työttömänä olleelle.

Myöntämisperusteiden erilaisuus johtaisi hyvin nopeasti epäterveisiin vinoutumiin. Kiinnostus opintojen loppuunsaattamiseen opiskeluvaiheessa heikkenisi huomattavasti jo nykyisen varsin huolestuttavasta tilanteesta, mikäli vuoden työsuhteen jälkeen saisi samasta opiskelusta $75 \%$ siitä, mitä työssä ollessa saisi palkkaa. Vuoden mittaisia työsuhteita syntyisi opiskelijoille huomattava määrä. Samoin omaa tai aviopuolisonsa lasta on 24-vuotiaana jo varsin moni ehtinyt hoitaa vuoden. Aikuisten opintotukeen oikeutettuja opiskelijoita tulisi olemaan huomattavan paljon. Sen ja opintojen viivästymisen aiheuttamia haittavaikutuksi ei työryhmä ole pyrkinyt lainkaan arvioimaan.

Työryhmä on ehdottamiensa säädösmuutosten yleisperusteluissa viitannut mm. Kansainvälisen työjärjestön, ILO:n hyväksymään taloudellisesti tuettua opintovapaata koskevaan yleissopimukseen (n:o 149) ja siihen liittyvään suositukseen (n:o 148). Työryhmä on kuitenkin jättänyt mainitsematta, että maissa, jotka ovat ratifioneet mainitun sopimuksen on taloudellisesti tuetun opintovapaan pituus erittäin huomattavasti esitettyjä aikoja lyhyempi. Esimerkiksi Englannissa 4-5 vuoden jaksolla yhteensä n. 23 päivää tai Länsi-Saksassa 5 päivää vuodessa. Toisaalta on todettava taloudellisesti tuetun opintovapaan rajoittuvan useimmissa maissa sellaiseen luottamushenkilökoulutukseen, jota Suomessa järjestetään keskeisten työmarkkinajärjestöjen välisten koulutussopimusten perusteella ammattiyhdistyskoulutuksena. Näin ollen Suomessa lainsäädännön ja sopimusten mukainen tämänhetkinen tilanne on hyvin verrattavissa tilanteeseen niissä harvoissa Euroopan maissa, jotka ovat kyseisen sopimuksen ratifioineet.

Työryhmän muistion sivulla 4 esitetty kustannusten tasausmenettely vääristää yritysten asemaa tuotantotoiminnassa ja johtaa terveiden ja kilpailukykyisten yritysten toiminnan heikkenemiseen. Ehdotus heikentää myös yritysten työllistämismahdollisuuksia pitkällä tähtäyksellä.

Ehdotus aviopuolison tulojen ja varallisuuden samoin kuin opiskelijan oman varallisuuden huomioon ottamatta jättämiseen on ristiriidassa niiden periaatteiden kanssa, joita toimikunta toisaalta esittää (yli 12000 markan kuukausitulot esteenä esim. kulukorvauuksen saamiseen). Muutosta ei pitäisi tehdä. Se on eräs peruste tarvetta harkittaessa.

Toimikunta esittää, että säätämällä työllisyyskoulutuksen etuuksien ulottamisesta ammatilliseen jatko- ja täydennyskoulutukseen sekä ammatilliseen peruskoulutukseen, työvoimaviranomaisilla olisi nykyistä monipuolisemmat mahdollisuudet yksilöllisiin koulutusratkaisuihin. Ehdotusta tehdessään työryhmä ei ole lainkaan ottanut huomioon niitä kustannuksia, jotka aiheuttaisivat työllisyyskoulutuksen etuuksien laajentamisesta esitetyllä tavalla.

Opintotuen ulottamista alle 16 viikkoa kestävään koulutukseen ei ole syytä toteuttaa muilta osin kuin mahdollisesti kulukorvauksena tietyistä kuluista.

Yhteenvetona voisi todeta, että omaehtoisesti toteutettavan aikuisopiskelun tuki pitäisi suhteuttaa perusopintovaiheessa olevien opintotukeen eikä rinnastaa sitä työsuhteeseen perustuvaan täydennyskoulutukseen. Yhteiskunnan tuki pitäisi paremminkin suunnata perusopintovaiheeseen, koska opiskelijoilla ei yleensä siinä vaiheessa ole omaa varallisuutta ja kokonaisuuden kannalta on parempi, että perusvalmiudet hankitaan mahdollisimman hyvinä jo nuoruusvuosina. 